\title{
Pemodelan Jumlah Pengangguran Usia Muda di Provinsi Jawa Timur Tahun 2019 dengan Regresi Binomial Negatif
}

\author{
(Modeling the Number of Youth Unemployment in East Java \\ Province in 2019 with Negative Binomial Regression) \\ Agriyandi Rizaldi ${ }^{*}$, Agung Priyo Utomo ${ }^{2}$ \\ ${ }^{1,2}$ Politeknik Statistika STIS \\ Jakarta, Indonesia

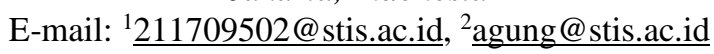

\begin{abstract}
ABSTRAK
Pengangguran merupakan permasalahan aktual dalam ketenagakerjaan di Indonesia. Pada tahun 2019, jumlah pengangguran di Indonesia sebanyak 7,10 juta orang, sebesar 56,02 persen atau 3,98 juta orang diantaranya adalah kelompok usia muda (15-24 tahun). Pengangguran usia muda menunjukkan adanya pemborosan sumber daya yang terbatas yang dapat menghambat potensi pertumbuhan ekonomi. Selain itu, juga berdampak pada lingkungan sosial, seperti kriminalitas, masalah kesehatan, dan kemiskinan. Provinsi Jawa Timur merupakan provinsi dengan jumlah pengangguran usia muda tertinggi kedua di Indonesia sebanyak 478.478 orang, padahal perekonomiannya menunjukkan pertumbuhan yang baik, bahkan lebih baik daripada pertumbuhan ekonomi nasional selama tahun 2015-2019. Penelitian ini bertujuan menganalisis variabel-variabel yang memengaruhi jumlah pengangguran usia muda di Provinsi Jawa Timur tahun 2019. Data yang digunakan adalah data Sakernas Agustus 2019 (backcasting). Metode analisis yang digunakan adalah regresi binomial negatif karena dapat mengatasi masalah overdispersi pada regresi Poisson. Hasil analisis menunjukkan bahwa terdapat pengaruh signifikan dari variabel upah minimum kabupaten/kota, serapan tenaga kerja sektor pertanian dan sektor industri pengolahan, pertumbuhan ekonomi, dan APK SMA terhadap jumlah pengangguran usia muda. Sementara itu, variabel persentase angkatan kerja usia muda lulusan SMA/sederajat dan investasi berpengaruh tidak signifikan terhadap jumlah pengangguran usia muda.
\end{abstract}

Kata kunci: pengangguran usia muda, Provinsi Jawa Timur, regresi Poisson, overdispersi, regresi binomial negatif

\begin{abstract}
Unemployment is an actual problem in employment in Indonesia. In 2019, the number of unemployment in Indonesia was 7,10 million people, 56,02 percent or 3,98 million of whom were the young age group (15-24 years old). Youth unemployment indicates a waste of limited human resources that can hinder potential economic growth. In addition, it also has an impact on the social environment, such as crime, health problems, and poverty. East Java was the province with the second highest number of youth unemployment in Indonesia as many as 478.478 people, even though the economy showed good growth, even better than the national economic growth during 2015-2019. This study aims to analyze the variables that affect the number of youth unemployment in East Java Province in 2019. The data used are Sakernas August 2019 (backcasting). The analytical method used is negative binomial regression because it can overcome overdispersion problem in Poisson regression. The results of analysis showed that there was significant effect of the variable regional minimum wage, labor absorption in agricultural and manufacturing sector, economic growth, and APK SMA on the number of youth unemployment. Meanwhile, variable percentage of young workforce who graduate high school/equivalent and invesment had no significant effect on the number of youth unemployment.
\end{abstract}

Keywords: youth unemployment, East Java Province, Poisson regression, overdispersion, negative binomial regression

\section{PENDAHULUAN}

Pengangguran merupakan fenomena yang masih menjadi permasalahan aktual dalam bidang ketenagakerjaan yang selalu dihadapi oleh banyak negara berkembang, tak terkecuali di Indonesia. Upaya untuk mengurangi jumlah pengangguran telah menjadi salah satu target pembangunan Indonesia. Berhasil atau tidaknya usaha untuk menanggulangi masalah pengangguran akan memengaruhi stabilitas sosial politik dalam kehidupan masyarakat dan kontinuitas dalam pembangunan ekonomi jangka panjang.

Pengangguran menyiratkan adanya potensi tenaga kerja yang tidak terserap dan tidak dimanfaatkan sehingga akan berdampak pada potensi pertumbuhan ekonomi. Akibatnya pertumbuhan ekonomi yang tercapai belum mencapai titik optimal. Selain menimbulkan masalah dalam bidang ekonomi, pengangguran juga dapat berdampak terhadap permasalahan sosial. Dongxu dan Zhongmin (2011) dan Maqbool, Sattar, dan Bhalli (2013) menjelaskan bahwa pengangguran dapat menimbulkan rasa keputusasaan (frustasi), hilangnya 
rasa percaya diri, depresi, penggunaan narkoba, masalah kesehatan, dan meningkatnya tindak kejahatan kriminal. Lebih jauh, pengangguran dapat berisiko meningkatkan kemiskinan (Saunders, 2002).

Berdasarkan data Badan Pusat Statistik (BPS), jumlah pengangguran di Indonesia tahun 2019 sebanyak 7,10 juta orang atau naik 31 ribu orang dibandingkan tahun 2018 (BPS, 2020). Dilihat berdasarkan kelompok usia, struktur pengangguran di Indonesia masih didominasi oleh pengangguran usia muda (15-24 tahun) dengan kontribusi sebesar 56,02 persen atau hampir empat juta orang. Pulau Jawa merupakan penyumbang terbesar pengangguran usia muda sebanyak 2,51 juta orang atau lebih dari 60 persen dari total pengangguran usia muda di Indonesia. Salah satu provinsi di Pulau Jawa yang memiliki jumlah pengangguran usia muda tertinggi adalah Provinsi Jawa Timur. Jumlahnya setara 57,29 persen dari total pengangguran di Provinsi Jawa Timur atau sebanyak 478.478 orang dan merupakan jumlah tertinggi kedua di Indonesia.

Menurut Ebaidalla (2016), kelompok usia muda memiliki kesempatan yang lebih kecil untuk mengakses dan bersaing di dunia kerja dibandingkan kelompok usia dewasa. Hal ini disebabkan kurangnya tingkat pendidikan, keterampilan, dan pengalaman kerja yang dimiliki kelompok usia muda (Elder, 2014; Fila, Mansingh, \& Legesse, 2016). Selain itu, kondisi perekonomian juga sangat berdampak terhadap pengangguran usia muda di suatu wilayah. Tenaga kerja akan terus terserap sepanjang kondisi perekonomian terus tumbuh dan berkembang ke arah positif. Penelitian yang dilakukan oleh Ebaidalla (2016) menunjukkan bahwa kenaikan pertumbuhan ekonomi berpengaruh signifikan menurunkan pengangguran usia muda.

Berdasarkan data BPS, selama tahun 2015-2019 perekonomian di Provinsi Jawa Timur menunjukkan pertumbuhan yang baik, bahkan pertumbuhannya lebih baik dibandingkan pertumbuhan ekonomi nasional. Meski demikian, pertumbuhan ekonomi yang tinggi ternyata masih belum mampu menyerap angkatan kerja usia muda dengan optimal sehingga masih menyisakan pengangguran usia muda yang banyak.

Oleh karena itu, penelitian ini bertujuan untuk mendeskripsikan gambaran umum jumlah pengangguran usia muda dan menganalisis variabel-variabel yang memengaruhinya di Provinsi Jawa Timur. Variabel respon yang digunakan adalah data cacah berupa jumlah pengangguran usia muda dengan mempertimbangkan jumlah angkatan kerja sebagai variabel offset sehingga metode analisis yang digunakan adalah analisis regresi Poisson dan regresi binomial negatif dengan unit analisis 38 kabupaten/kota di Provinsi Jawa Timur tahun 2019.

\section{METODE}

\section{Landasan Teori}

Perserikatan Bangsa-Bangsa (PBB) mendefinisikan kelompok usia muda adalah mereka yang berusia antara 15-24 tahun (ILO, 2001). Definisi usia muda ini sebenarnya tidak mutlak sehingga dapat bervariasi dan berbeda di tiap negara. Namun, menurut ILO (2004), definisi kelompok umur 15-24 tahun ini merupakan definisi yang sering digunakan secara internasional untuk usia muda. Pengangguran usia muda dapat diartikan sebagai penduduk angkatan kerja berusia 15-24 tahun yang tidak memiliki pekerjaan, sedang mencari pekerjaan, sedang mempersiapkan usaha, tidak mencari pekerjaan karena merasa putus asa, ataupun sudah memiliki pekerjaan tetapi belum mulai bekerja. Pengangguran usia muda merupakan salah satu permasalahan serius yang mengindikasikan adanya pemborosan sumber daya yang terbatas sehingga dapat menghambat potensi pertumbuhan ekonomi dalam jangka panjang (Gontkovičová, Mihalčová, \& Pružinský, 2015). Selain berdampak pada ekonomi, pengangguran usia muda juga berdampak pada permasalahan sosial baik bagi individu maupun lingkungan (Bell \& Blanchflower, 2011).

Variabel yang sangat berhubungan dengan pengangguran adalah upah minimum, Menurut Bappenas (2003) peningkatan upah minimum terus-menerus tanpa dibarengi dengan peningkatan produktivitas dan pertumbuhan ekonomi yang cepat dapat berpotensi mengurangi kesempatan kerja. Lebih jauh, dampak terbesar dari kenaikan upah minimum yang terlalu tinggi akan dialami oleh pekerja perempuan, pekerja usia muda, dan pekerja kurang terdidik. Gorry (2013) dan Ebaidalla (2016) juga menjelaskan bahwa pengangguran usia muda sangat sensitif dan akan terdampak besar dengan adanya perubahan upah minimum. Pekerja usia muda sering dianggap memiliki pengalaman dan keterampilan yang rendah sehingga dengan naiknya upah yang menaikkan biaya produksi maka pengusaha cenderung lebih memilih untuk mempekerjakan pekerja berketerampilan tinggi daripada pekerja usia muda, dengan demikian akan timbul pengangguran usia muda.

Sektor pertanian dan sektor industri pengolahan dianggap sebagai sektor yang dapat menyerap tenaga kerja usia muda. Menurut Elhorst (2003) angka pengganda tenaga kerja (employment multiplier) pada kedua sektor ini secara umum lebih besar dibandingkan pada sektor jasa yang sebagian besar bergantung pada permintaan dari kedua sektor ini. Nugroho, Waluyati, dan Jamhari (2018) menjelaskan bahwa dilihat dari jenis pekerjaannya, sektor pertanian biasanya tidak mensyaratkan pendidikan dan keterampilan yang tinggi sehingga dapat dimasuki oleh tenaga kerja usia muda, khususnya mereka yang kurang dalam pendidikan dan 
keterampilan. Daud (2017) dan Muhtamil (2017) menyatakan bahwa pertumbuhan pada sektor industri secara langsung akan berdampak pada peningkatan serapan tenaga kerja sehingga mampu mengurangi pengangguran.

Mankiw (2010) menjelaskan bahwa pengangguran sangat berhubungan dengan pertumbuhan ekonomi, pertumbuhan ekonomi yang meningkat menunjukkan adanya peningkatan produksi barang dan jasa yang dihasilkan, untuk meningkatkan produksi tersebut dibutuhkan faktor produksi yang lebih banyak, salah satunya adalah tenaga kerja. Pertumbuhan ekonomi memiliki dampak yang lebih besar terhadap kelompok usia muda dibandingkan terhadap kelompok usia lainnya (Choudhry, Marelli, \& Signorelli, 2012).

Variabel lain yang berhubungan erat dengan pengangguran usia muda adalah pendidikan, baik itu partisipasi dalam pendidikan maupun tingkat pendidikan yang dimiliki kelompok usia muda itu sendiri. Dietrich (2012) menyatakan bahwa salah satu cara untuk mencegah dan mengurangi pengangguran pada kelompok usia muda adalah dengan meningkatkan partisipasi kelompok usia muda ke dalam pendidikan. Artinya, kelompok usia muda harus terus didorong untuk bersekolah setinggi-tingginya dan tidak memaksakan untuk masuk ke pasar tenaga kerja dengan pengetahuan dan keterampilan yang rendah. Salvador dan Killinger (2008) juga menjelaskan bahwa keikutsertaan dalam pendidikan dan program pelatihan dapat memengaruhi seberapa besar kemungkinan kelompok usia muda menjadi pengangguran, semakin banyak kelompok usia muda yang berpartisipasi dalam pendidikan, pengangguran usia muda cenderung semakin menurun. Tingkat pendidikan yang dimiliki kelompok usia muda juga memegang peran penting dalam usaha mencari pekerjaan, Pindyck dan Rubinfeld (2013) menyatakan bahwa tingkat pendidikan dipandang sebagai sinyal kuat dalam pasar tenaga kerja, tingkat pendidikan seseorang dapat secara langsung maupun tidak langsung akan berpengaruh dalam peningkatan produktivitas melalui pengetahuan informasi dan keterampilan yang dimiliki seseorang tersebut. Kabaklarli, Hazeler, dan Bulus (2011) juga menjelaskan bahwa kelompok usia muda yang berpendidikan tinggi lebih efisien dalam mencari dan memperoleh pekerjaan serta mendapatkan upah yang layak dibandingkan dengan kelompok usia muda yang berpendidikan rendah.

Zeb, Fu, dan Sharif (2014) memandang bahwa investasi berperan penting terhadap peningkatan ekonomi karena selain sebagai pembentukan modal, investasi juga akan mendorong terciptanya lapangan kerja baru, peningkatan penggunaan teknologi, dan peningkatan pertumbuhan ekonomi secara keseluruhan. Hal serupa juga dijelaskan oleh Dewi (2019), pertumbuhan investasi dalam jangka panjang akan berpengaruh pada berkurangnya jumlah pengangguran, hal ini karena pertumbuhan investasi akan berdampak langsung pada peningkatan produktivitas karena adanya penambahan barang-barang modal (stok kapital) termasuk penambahan tenaga kerja sehingga meningkatkan kesempatan kerja dan mengurangi pengangguran.

\section{Metode Analisis}

Metode analisis yang digunakan dalam penelitian ini dapat dibedakan menjadi analisis deskriptif dan analisis inferensi. Analisis deskriptif digunakan untuk mendeskripsikan gambaran umum mengenai jumlah pengangguran usia muda beserta variabel-variabel yang berhubungan dengannya di Provinsi Jawa Timur tahun 2019 yang disajikan dalam grafik dan peta tematik. Adapun analisis inferensi digunakan untuk mengetahui pengaruh variabel prediktor terhadap variabel respon dengan mempertimbangkan variabel offset. Data variabel respon dalam penelitian ini adalah data cacah (count) sehingga metode regresi yang digunakan adalah metode yang mampu memenuhi karakteristik data cacah, yaitu data yang tidak bernilai negatif. Selain itu, data cacah variabel respon dalam penelitian ini juga disesuaikan atau dikontrol dengan variabel offset. Variabel offset berperan sebagai variabel yang menyeimbangkan atau memproporsionalkan data cacah variabel respon terhadap suatu data variabel yang berkaitan erat dengannya. Oleh karena itu, metode regresi yang digunakan dalam penelitian ini adalah regresi Poisson dan regresi binomial negatif dengan mempertimbangkan variabel offset. Berikut adalah model regresi yang digunakan (Hilbe, 2011):

$$
Y_{i}=\exp \left(\beta_{0}+\beta_{1} X_{1 i}+\beta_{2} X_{2 i}+\cdots+\beta_{p} X_{p i}+\ln \left(n_{i}\right)\right)
$$

Keterangan:

$\mathrm{Y}_{\mathrm{i}}$ : Variabel respon

$\beta_{0}:$ Intercept

$\beta_{\mathrm{j}} \quad$ : Koefisien regresi variabel prediktor ke-j

$\mathrm{X}_{\mathrm{ji}}$ : Variabel prediktor ke-j, $\mathrm{j}=1,2, \ldots, \mathrm{p}$

$\mathrm{n} \quad$ : Variabel offset

i : Kabupaten/kota di Provinsi Jawa Timur, i=1, 2, .., 38

Tahapan analisis inferensi dimulai dengan pendugaan parameter regresi Poisson. Kemudian, pemeriksaan kolinearitas antarvariabel prediktor dengan nilai VIF yang lebih besar daripada 10 menunjukkan adanya multikolinearitas. Selanjutnya, pemeriksaan equidispersi pada regresi Poisson, jika equidispersi tidak 
terpenuhi dan terdapat masalah overdispersi maka dilakukan pendugaan parameter regresi binomial negatif untuk mengatasi masalah tersebut. Pengujian signifikansi parameter regresi dilakukan secara simultan (bersama-sama) dan parsial. Pengujian selanjutnya adalah pengujian kebaikan model dengan uji signifikansi parameter dispersi. Pengujian ini bertujuan untuk mengetahui model terbaik antara model regresi Poisson dan model regresi binomial negatif. Kemudian, melakukan interpretasi model terbaik yang dihasilkan.

\section{Data dan Sumber Data}

Penelitian ini mencakup 38 kabupaten/kota di Provinsi Jawa Timur pada tahun 2019. Data yang digunakan merupakan data sekunder berupa data cross-section tahun 2019 yang diperoleh dari berbagai sumber, yaitu data mentah (raw data) Survei Angkatan Kerja Nasional (Sakernas) Agustus 2019 (backcasting) yang dilaksanakan oleh BPS, publikasi BPS, Disnakertrans Jawa Timur, dan Badan Koordinasi Penanaman Modal (BKPM). Variabel respon berupa data cacah (count) jumlah pengangguran usia muda (Y) dengan variabel offset jumlah angkatan kerja (n). Adapun variabel prediktor terdiri dari tujuh variabel, yaitu upah minimum kabupaten/kota $\left(\mathrm{X}_{1}\right)$, persentase serapan tenaga kerja pada sektor pertanian $\left(\mathrm{X}_{2}\right)$, persentase serapan tenaga kerja pada sektor industri pengolahan $\left(\mathrm{X}_{3}\right)$, pertumbuhan ekonomi $\left(\mathrm{X}_{4}\right)$, angka partisipasi kasar SMA $\left(\mathrm{X}_{5}\right)$, persentase angkatan kerja usia muda lulusan SMA/sederajat $\left(\mathrm{X}_{6}\right)$, dan investasi $\left(\mathrm{X}_{7}\right)$.

\section{HASIL DAN PEMBAHASAN}

\section{Gambaran Umum Jumlah Pengangguran Usia Muda di Provinsi Jawa Timur Tahun 2019}

Berdasarkan hasil Sakernas Agustus 2019, pengangguran usia muda di Provinsi Jawa Timur sebanyak 478.478 orang atau setara 57,29 persen dari total pengangguran keseluruhan. Kota Surabaya merupakan wilayah dengan jumlah pengangguran usia muda tertinggi sebanyak 45.953 orang, sedangkan jumlah pengangguran usia muda paling sedikit berada di Kota Mojokerto sebanyak 667 orang. Berdasarkan Gambar 1, semakin gelap warna wilayah menunjukkan semakin banyak jumlah penganggurannya. Terdapat lima kabupaten/kota dengan jumlah pengangguran usia muda kategori tinggi, yaitu Kabupaten Sidoarjo, Kabupaten Jember, Kabupaten Pasuruan, Kabupaten Malang, dan Kota Surabaya. Sementara itu, terdapat sepuluh kabupaten/kota dengan kategori sedang dan sebanyak 23 kabupaten/kota lainnya termasuk kategori rendah.

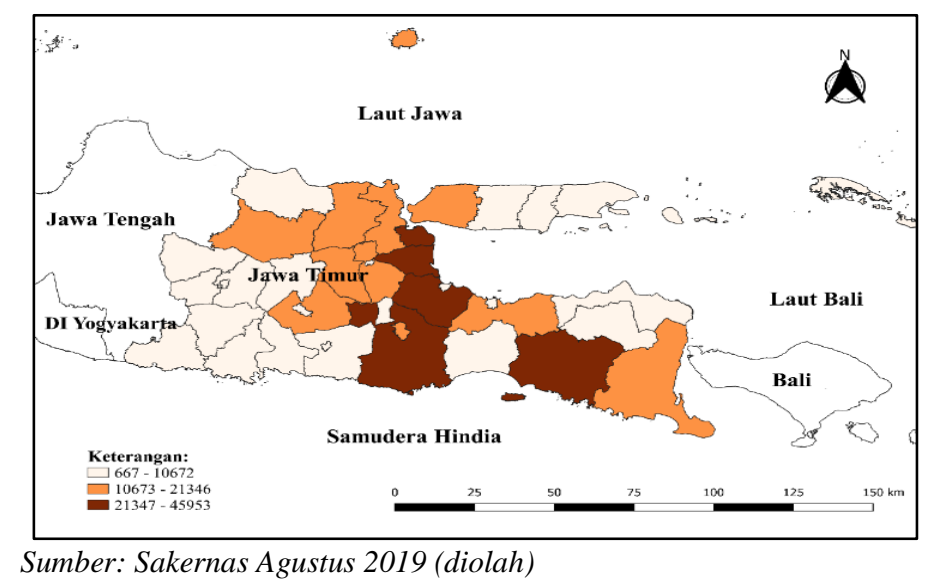

Gambar 1. Sebaran jumlah pengangguran usia muda di Provinsi Jawa Timur tahun 2019

\section{Tingkat Pendidikan Angkatan Kerja Usia Muda}

Persentase angkatan kerja usia muda lulusan SMA/sederajat di Provinsi Jawa Timur tahun 2019 sebesar 56,86 persen. Artinya, dari 100 orang angkatan kerja usia muda terdapat 56 sampai 57 orang diantaranya memiliki pendidikan SMA/sederajat. Sebagian besar kabupaten/kota di Provinsi Jawa Timur memiliki persentase angkatan kerja usia muda lulusan SMA/sederajat kategori sedang, yaitu antara 42,39 sampai 58,30 persen. Kota Madiun, Kabupaten Sidoarjo, dan Kabupaten Mojokerto merupakan tiga wilayah dengan persentase paling tinggi sebesar 72,31 persen, 73,15 persen, dan 74,30 persen. Adapun Kabupaten Sampang, Kabupaten Jember, dan Kabupaten Lumajang merupakan tiga kabupaten dengan persentase paling rendah hanya sebesar 27,69 persen, 39,71 persen, dan 40,17 persen. Dilihat dari jumlah pengangguran usia muda, kabupaten/kota dengan persentase angkatan kerja usia muda lulusan SMA/sederajat yang tinggi memiliki jumlah pengangguran yang rendah, begitu pula sebaliknya. Hal ini menunjukkan indikasi awal adanya 
hubungan negatif antara persentase angkatan kerja usia muda lulusan SMA/sederajat dan jumlah pengangguran usia muda.

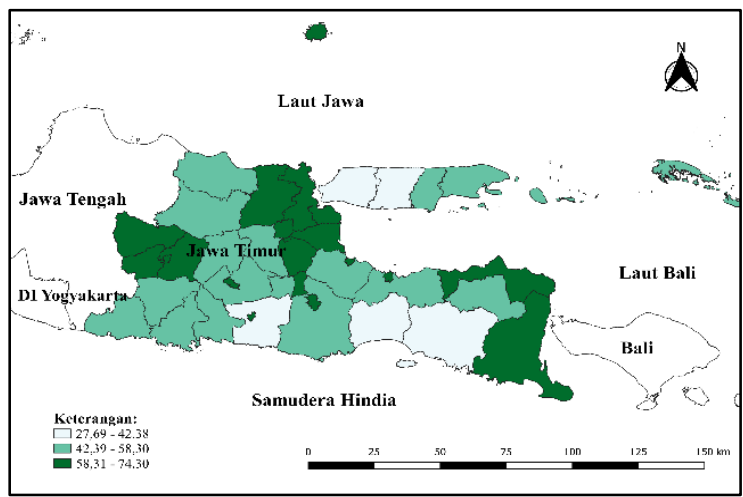

Sumber: Sakernas Agustus 2019 (diolah)

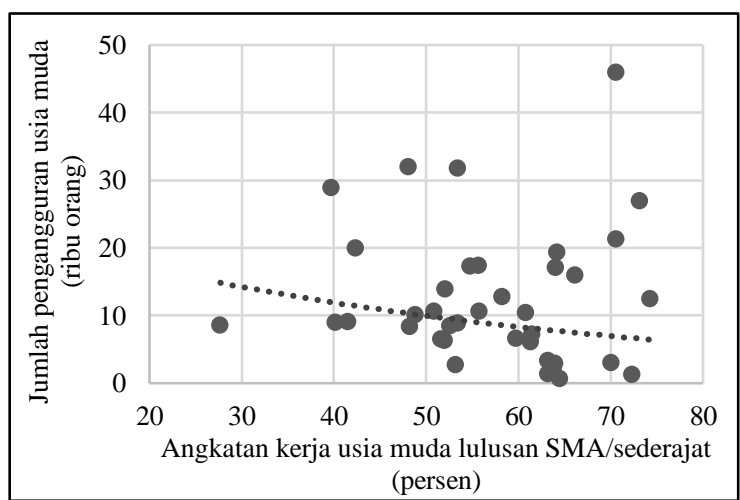

(persen)

Gambar 2. Sebaran persentase angkatan kerja usia muda lulusan SMA/sederajat dan scatter plot terhadap jumlah pengangguran usia muda di Provinsi Jawa Timur tahun 2019

\section{Sektor Pertanian dan Sektor Industri Pengolahan}

Kontribusi dan peran sektor pertanian dan sektor industri pengolahan dalam penyerapan tenaga kerja di Provinsi Jawa Timur cukup besar. Berdasarkan hasil Sakernas Agustus 2019, hampir separuh tenaga kerja terserap hanya pada kedua sektor ini dengan masing-masing sektor pertanian sebesar 31 persen dan sektor industri pengolahan sebesar 16 persen. Secara umum, kedua sektor ini menjadi sektor yang mendominasi serapan tenaga kerja dan hal tersebut terjadi di hampir seluruh kabupaten/kota. Gabungan keduanya mampu menyerap lebih dari 40 persen tenaga kerja di 28 kabupaten/kota, bahkan di 19 kabupaten/kota mampu menyerap lebih dari 50 persen tenaga kerja.

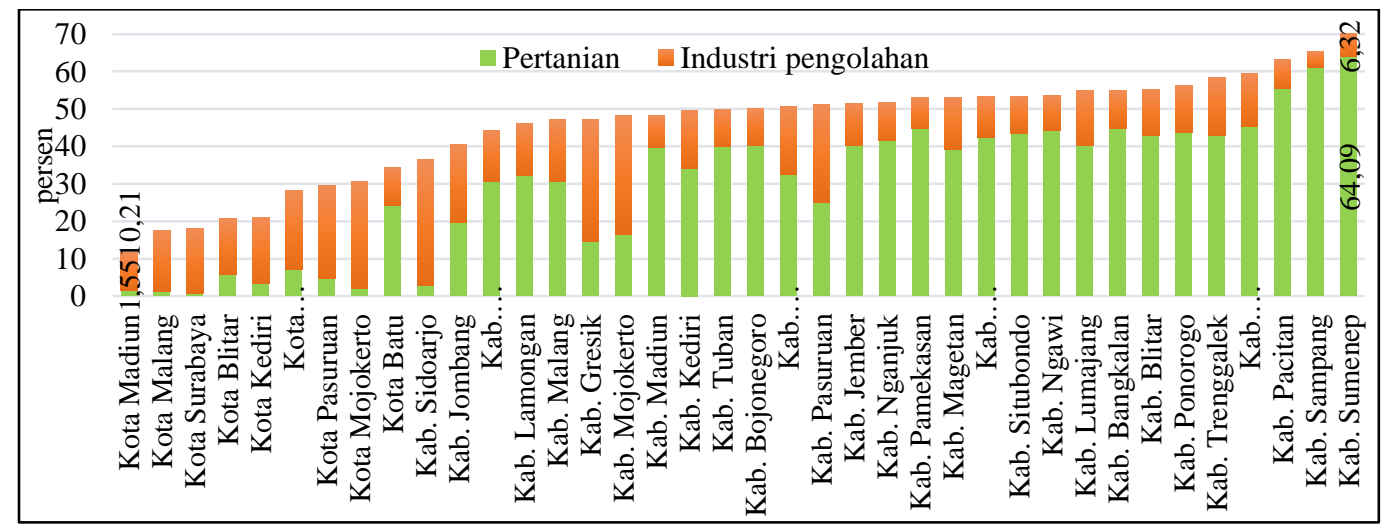

Sumber: Sakernas Agustus 2019 (diolah)

Gambar 3. Persentase serapan tenaga kerja pada sektor pertanian dan sektor industri pengolahan menurut kabupaten/kota di Provinsi Jawa Timur tahun 2019

\section{Upah Minimum Kabupaten/kota (UMK)}
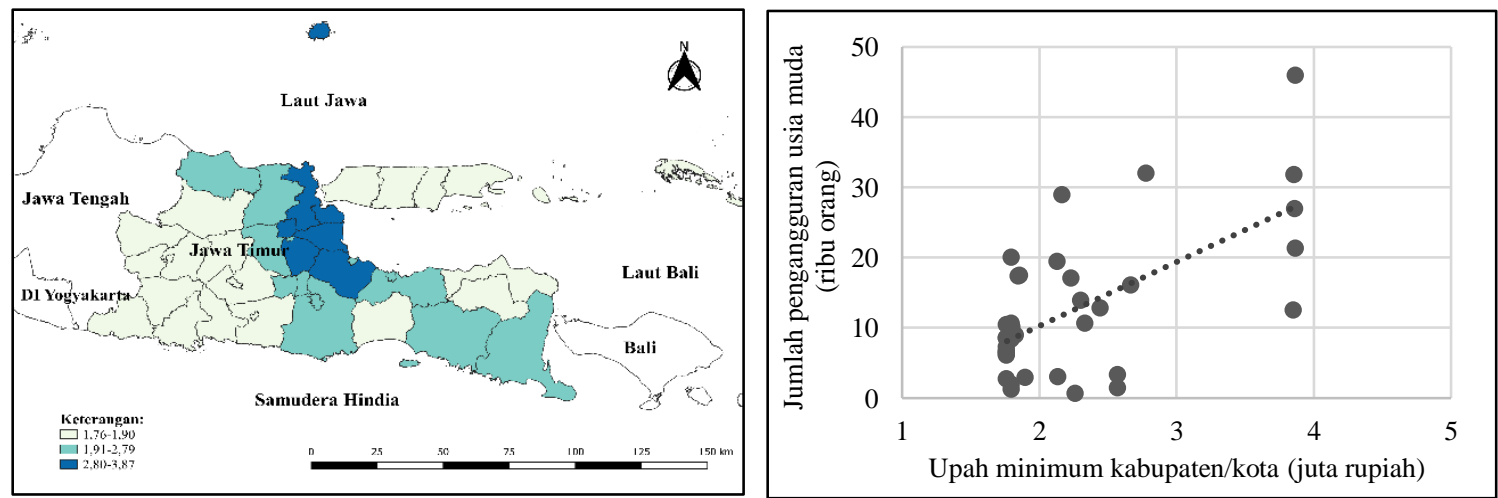

Sumber: Disnakertrans Provinsi Jawa Timur dan Sakernas Agustus 2019 (diolah)

Gambar 4. Sebaran UMK dan scatter plot terhadap jumlah pengangguran usia muda di Provinsi Jawa Timur tahun 2019 
Sebagian besar kabupaten/kota di Provinsi Jawa Timur memiliki UMK kurang dari 1,90 juta rupiah. UMK paling rendah terdapat pada beberapa kabupaten/kota hanya sebesar 1,76 juta rupiah, sedangkan UMK paling tinggi sebesar lebih dari 3,80 juta rupiah terdapat pada lima kabupaten/kota. Jika dibandingkan, UMK tertinggi tersebut bernilai dua kali lebih besar dibandingkan UMK terendah. Kabupaten/kota dengan UMK rendah memiliki jumlah pengangguran usia muda yang rendah, begitu pula sebaliknya. Hal ini menunjukkan indikasi awal adanya hubungan positif antara UMK dan jumlah pengangguran usia muda.

\section{Pertumbuhan Ekonomi}

Pertumbuhan ekonomi Provinsi Jawa Timur pada tahun 2019 sebesar 5,52 persen, angka ini sedikit lebih besar dibandingkan pertumbuhan ekonomi nasional yang sebesar 5,02 persen. Kabupaten/kota di Provinsi Jawa Timur memiliki pertumbuhan ekonomi yang tidak terlalu bervariasi hanya berada pada rentang 4,5 sampai 6,5 persen, kecuali pada beberapa kabupaten/kota, seperti Kabupaten Sumenep, Kabupaten Bangkalan, dan Kabupaten Sampang yang pertumbuhan ekonominya relatif kecil sebesar kurang dari 1,5 persen. Kota Surabaya, Kabupaten Bojonegoro, dan Kota Batu merupakan wilayah dengan pertumbuhan ekonomi tertinggi sebesar lebih dari enam persen. Secara umum, kabupaten/kota dengan pertumbuhan ekonomi cukup tinggi memiliki jumlah pengangguran lebih rendah dibandingkan kabupaten/kota dengan pertumbuhan ekonomi rendah. Hal ini menunjukkan indikasi awal adanya hubungan negatif antara pertumbuhan ekonomi dan jumlah pengangguran usia muda.
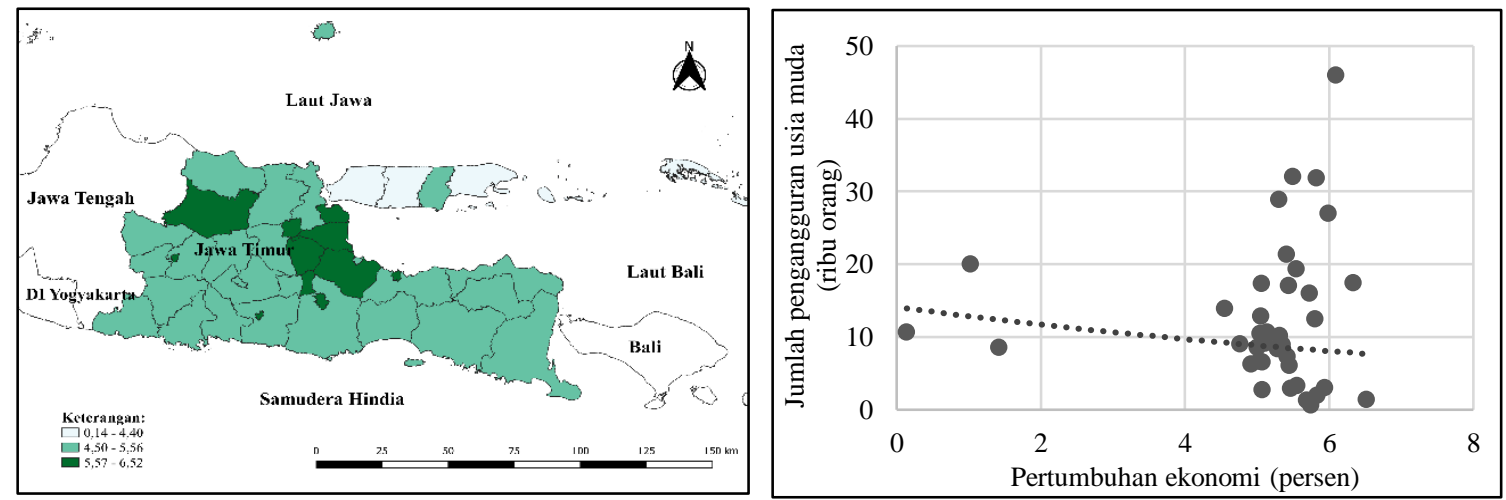

Sumber: BPS dan Sakernas Agustus 2019 (diolah)

Gambar 5. Sebaran pertumbuhan ekonomi dan scatter plot terhadap jumlah pengangguran usia muda di Provinsi Jawa Timur tahun 2019

\section{Angka Partisipasi Kasar SMA/sederajat (APK SMA)}
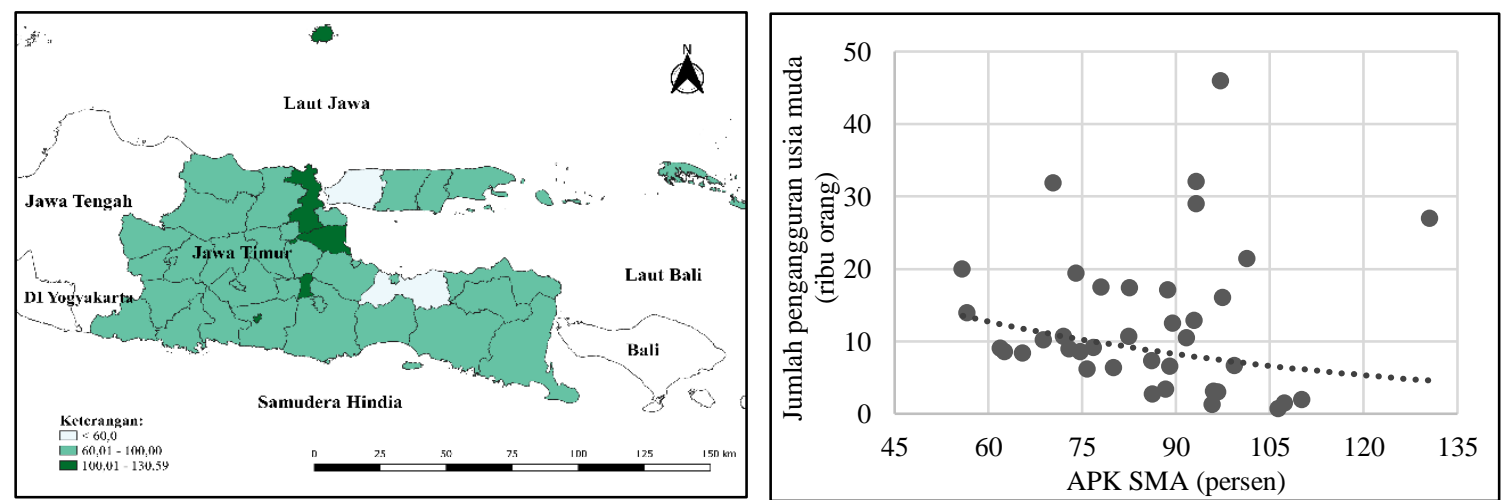

Sumber: BPS dan Sakernas Agustus 2019 (diolah)

Gambar 6. Sebaran APK SMA dan scatter plot terhadap jumlah pengangguran usia muda di Provinsi Jawa Timur tahun 2019

APK SMA di Provinsi Jawa Timur tahun 2019 sebesar 84,80 persen. Artinya, dari 100 orang penduduk usia 16-18 tahun terdapat 84 sampai 85 orang diantaranya sedang bersekolah jenjang SMA/sederajat. Terdapat dua kabupaten/kota di Provinsi Jawa Timur yang memiliki APK SMA kurang dari 60 persen, yaitu Kabupaten Bangkalan dan Kabupaten Probolinggo. Sementara itu, terdapat lima kabupaten/kota dengan APK SMA lebih dari 100 persen, yaitu Kabupaten Gresik, Kota Mojokerto, Kota Batu, Kota Blitar, dan Kabupaten Sidoarjo. Angka yang melebihi 100 persen ini dapat terjadi karena penduduk yang berusia diluar rentang 16-18 tahun dan bersekolah jenjang SMA/sederajat juga dimasukkan dalam penghitungan. Kabupaten/kota dengan APK SMA cukup tinggi memiliki jumlah pengangguran yang lebih rendah dibandingkan kabupaten/kota dengan 
APK SMA rendah. Hal ini menunjukkan indikasi awal adanya hubungan negatif antara APK SMA dan jumlah pengangguran usia muda.

\section{Investasi}

Nilai investasi di Provinsi Jawa Timur pada tahun 2019 mencapai 58,45 triliun rupiah. Sebagian besar kabupaten/kota mendapatkan investasi kurang dari satu triliun rupiah, bahkan terdapat dua kabupaten/kota yang tidak mendapat investasi, yaitu Kabupaten Magetan dan Kabupaten Sampang. Sementara itu, nilai investasi tertinggi terdapat di Kabupaten Probolinggo, Kabupaten Pasuruan, dan Kota Surabaya sebesar lebih dari delapan triliun rupiah. Kabupaten/kota dengan nilai investasi tinggi justru memiliki jumlah pengangguran lebih tinggi dibandingkan kabupaten/kota dengan nilai investasi rendah ataupun tidak mendapat investasi. Hal ini menunjukkan indikasi awal adanya hubungan positif antara investasi dan jumlah pengangguran usia muda.

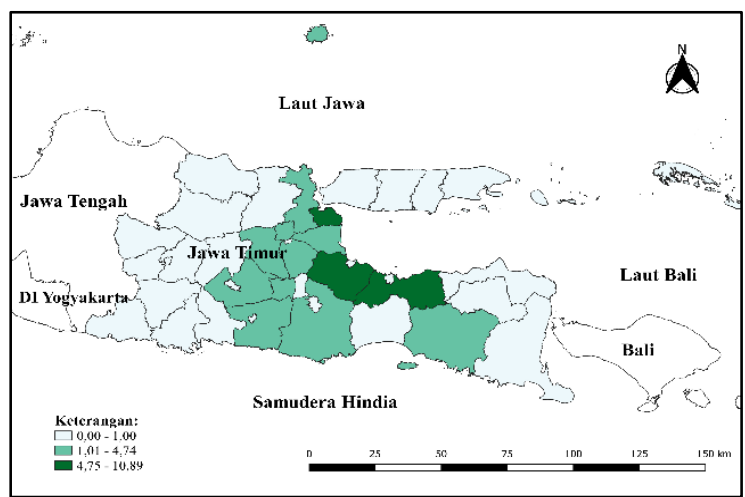

Sumber: BKPM dan Sakernas Agustus 2019 (diolah)

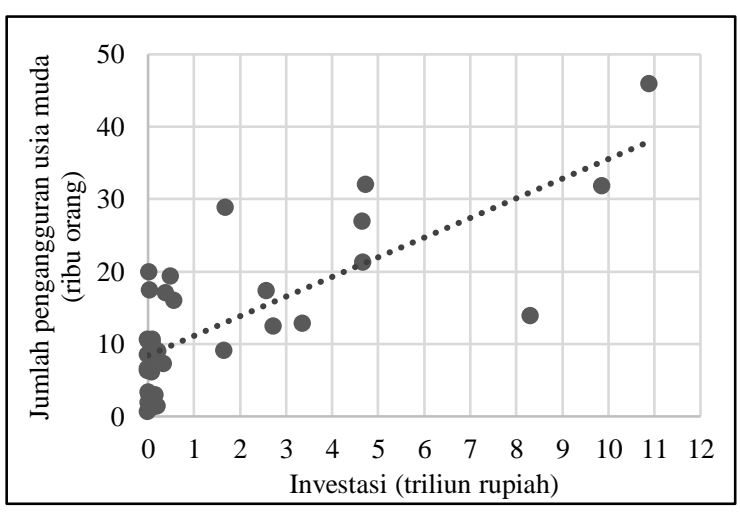

Investasi (triliun rupiah)

Gambar 7. Sebaran investasi dan scatter plot terhadap jumlah pengangguran usia muda di Provinsi Jawa Timur tahun 2019

\section{Pemodelan Jumlah Pengangguran Usia Muda Berdasarkan Variabel-variabel yang Memengaruhinya di Provinsi Jawa Timur Tahun 2019}

Jumlah pengangguran usia muda merupakan data jumlah (count) sehingga model awal yang digunakan adalah model regresi Poisson seperti pada persamaan (1). Berikut persamaan regresi Poisson yang terbentuk:

$$
\begin{gathered}
\hat{Y}_{i} / n_{i}=\exp \left(-2,6154+0,2344 X_{1 i}-0,0131 X_{2 i}-0,0042 X_{3 i}-0,0675 X_{4 i}-0,0073 X_{5 i}\right. \\
\left.-0,0060 X_{6 i}-0,0116 X_{7 i}\right)
\end{gathered}
$$

Setelah membentuk persamaan regresi Poisson, dilakukan pemeriksaan kolinearitas dengan kriteria nilai VIF. Berdasarkan Tabel 1, variabel $\mathrm{X}_{1}$ memiliki nilai VIF lebih besar daripada 10 yang mengindikasikan adanya masalah multikolinearitas. Oleh karena variabel ini penting dalam penelitian maka variabel ini tidak dibuang dan tetap digunakan.

Tabel 1. Hasil pemeriksaan kolinearitas pada model regresi Poisson

\begin{tabular}{cccccccc}
\hline Variabel & $\mathrm{X}_{1}$ & $\mathrm{X}_{2}$ & $\mathrm{X}_{3}$ & $\mathrm{X}_{4}$ & $\mathrm{X}_{5}$ & $\mathrm{X}_{6}$ & $\mathrm{X}_{7}$ \\
\hline VIF & 11,50 & 5,29 & 4,13 & 1,75 & 2,19 & 3,09 & 5,29 \\
\hline Sumber: Hasil pengolahan & & & & & &
\end{tabular}

Untuk menangani masalah multikolinearitas ini, dilakukan pembentukan variabel prediktor baru yang berasal dari kombinasi beberapa variabel prediktor. Variabel baru yang dibentuk adalah kombinasi jumlah dari variabel $\mathrm{X}_{2}$ dan variabel $\mathrm{X}_{3}$ sebagai satu variabel prediktor baru berupa persentase serapan tenaga kerja pada sektor pertanian dan sektor industri pengolahan yang selanjutnya disimbolkan dengan $\mathrm{X}_{23}$. Penggabungan kedua variabel prediktor tersebut didasarkan pada nilai VIF variabel $\mathrm{X}_{2}$ yang cukup tinggi yang mengindikasikan terjadi multikolinearitas antara variabel $X_{1}$ dan $X_{2}$. Kemudian, dilakukan kembali pembentukan model regresi Poisson dan pemeriksaan kolinearitas antarvariabel prediktor yang baru. Berikut persamaan regresi Poisson yang terbentuk:

$$
\begin{gathered}
\hat{Y}_{i} / n_{i}=\exp \left(-2,8571+0,3224 X_{1 i}-0,0116 X_{23 i}-0,0577 X_{4 i}-0,0069 X_{5 i}-0,0054 X_{6 i}\right. \\
\left.-0,0195 X_{7 i}\right)
\end{gathered}
$$

Berdasarkan Tabel 2, seluruh variabel prediktor memiliki nilai VIF yang relatif jauh lebih kecil daripada 10 sehingga tidak ada masalah multikolineritas. Kemudian, dilakukan pemeriksaan asumsi equidispersi pada persamaan regresi Poisson yang terbentuk. Berdasarkan hasil pemeriksaan, diperoleh nilai deviance sebesar 
21948 dengan derajat bebas 31 sehingga nilai rasio dispersinya sebesar 708 yang jauh lebih besar daripada satu sehingga dapat dikatakan persamaan regresi Poisson yang terbentuk mengalami overdispersi.

Tabel 2. Hasil pemeriksaan kolinearitas pada model regresi Poisson dengan variabel prediktor baru

\begin{tabular}{lcccccc}
\hline Variabel & $\mathrm{X}_{1}$ & $\mathrm{X}_{23}$ & $\mathrm{X}_{4}$ & $\mathrm{X}_{5}$ & $\mathrm{X}_{6}$ & $\mathrm{X}_{7}$ \\
\hline VIF & 5,88 & 2,72 & 1,59 & 2,12 & 3,01 & 4,46 \\
\hline
\end{tabular}

Sumber: Hasil pengolahan

Oleh karena hasil regresi Poisson mengalami overdispersi maka hasil dugaan parameternya tidak dapat digunakan karena sudah tidak akurat. Untuk mengatasinya, dilakukan pembentukan model regresi binomial negatif. Berikut persamaan regresi binomial negatif yang terbentuk:

$$
\begin{aligned}
\hat{Y}_{i} / n_{i}=\exp ( & -2,8799+0,2879 X_{1 i}-0,0120 X_{23 i}-0,0774 X_{4 i}-0,0080 X_{5 i}-0,0006 X_{6 i} \\
& \left.-0,0060 X_{7 i}\right)
\end{aligned}
$$

Kemudian dilakukan pengujian secara simultan (bersama-sama) pengaruh seluruh variabel prediktor terhadap jumlah pengangguran usia muda. Berikut hipotesis pengujian ini:

$\mathrm{H}_{0}: \beta_{1}=\beta_{23}=\beta_{4}=\beta_{5}=\beta_{6}=\beta_{7}=0$ (seluruh variabel prediktor berpengaruh tidak signifikan terhadap variabel respon).

$\mathrm{H}_{1}$ : Minimal satu $\beta_{\mathrm{j}} \neq 0, \mathrm{j}=1,23,4,5,6,7$ (minimal satu variabel prediktor berpengaruh signifikan terhadap variabel respon).

Berdasarkan hasil pengujian, diperoleh nilai likelihood ratio sebesar 19,83 yang lebih besar daripada nilai chi-square pada tingkat signifikansi 10 persen $\left(\chi_{0,1 ; 6}^{2}=10,65\right)$ sehingga keputusan pengujiannya tolak $\mathrm{H}_{0}$ yang menunjukkan seluruh variabel prediktor secara bersama-sama berpengaruh signifikan terhadap jumlah pengangguran usia muda.

Setelah pengujian secara simultan, dilakukan pengujian secara parsial pengaruh setiap variabel prediktor terhadap jumlah pengangguran usia muda. Berikut hipotesis pengujian ini:

$\mathrm{H}_{0}: \beta_{\mathrm{j}}=0$ (variabel prediktor ke-j berpengaruh tidak signifikan terhadap variabel respon dengan asumsi terdapat variabel prediktor lain di dalam model).

$\mathrm{H}_{1}: \beta_{\mathrm{j}} \neq 0, \mathrm{j}=1,23,4,5,6,7$ (variabel prediktor ke-j berpengaruh signifikan terhadap variabel respon dengan asumsi terdapat variabel prediktor lain di dalam model).

Berdasarkan Tabel 3, terdapat empat variabel prediktor, yaitu variabel $\mathrm{X}_{1}, \mathrm{X}_{23}, \mathrm{X}_{4}$, dan $\mathrm{X}_{5}$ yang memiliki nilai mutlak Wald statistic $\left(\left|Z_{\mathrm{j}}\right|\right)$ lebih besar daripada nilai $\mathrm{Z}$ (normal baku) pada tingkat signifikansi 10 persen $\left(\mathrm{Z}_{0,1 / 2}=1,65\right)$ sehingga keputusan pengujiannya tolak $\mathrm{H}_{0}$ yang menunjukkan bahwa keempat variabel prediktor tersebut secara parsial berpengaruh signifikan terhadap jumlah pengangguran usia muda. Adapun dua variabel prediktor lainnya, yaitu variabel $\mathrm{X}_{6}$ dan $\mathrm{X}_{7}$ memiliki nilai mutlak Wald statistic lebih kecil daripada nilai $\mathrm{Z}$ pada tingkat signifikansi 10 persen yang berarti kedua variabel prediktor tersebut berpengaruh tidak signifikan terhadap jumlah pengangguran usia muda.

Tabel 3. Hasil pendugaan parameter regresi binomial negatif

\begin{tabular}{lccccccc}
\hline Variabel & Intercept & $\mathrm{X}_{1}$ & \multicolumn{1}{c}{$\mathrm{X}_{23}$} & \multicolumn{1}{c}{$\mathrm{X}_{4}$} & \multicolumn{1}{c}{$\mathrm{X}_{5}$} & \multicolumn{1}{c}{$\mathrm{X}_{6}$} & \multicolumn{1}{c}{$\mathrm{X}_{7}$} \\
\hline Koefisien $\left(\widehat{\beta}_{\mathrm{j}}\right)$ & $-2,8799$ & 0,2879 & $-0,0120$ & $-0,0774$ & $-0,0080$ & $-0,0006$ & $-0,0060$ \\
Standard error $\left(\mathrm{se}\left(\widehat{\beta}_{\mathrm{j}}\right)\right)$ & 0,5354 & 0,1177 & 0,0045 & 0,0415 & 0,0040 & 0,0071 & 0,0260 \\
$\exp \left(\widehat{\beta}_{\mathrm{j}}\right)$ & 0,0561 & 1,3337 & 0,9881 & 0,9255 & 0,9920 & 0,9994 & 0,9940 \\
Wald statistic $\left(\mathrm{Z}_{\mathrm{j}}\right)$ & $-5,3789$ & 2,4470 & $-2,6664$ & $-1,8641$ & $-1,9869$ & $-0,0903$ & $-0,2327$ \\
\hline
\end{tabular}

Sumber: Hasil pengolahan

Setelah pengujian secara simultan dan parsial, dilakukan pengujian kebaikan model dengan uji signifikasi parameter dispersi $(\alpha)$. Berikut hipotesis pada pengujian ini:

$\mathrm{H}_{0}: \alpha=0$ (keadaan equidispersi, regresi Poisson relatif sama baiknya dengan regresi binomial negatif).

$\mathrm{H}_{1}: \alpha>0$ (keadaan overdispersi, regresi binomial negatif lebih baik daripada model regresi Poisson).

Berdasarkan hasil pengujian, diperoleh nilai likelihood ratio sebesar 21665 yang lebih besar daripada nilai chi-square pada tingkat signifikansi 10 persen $\left(\chi_{0,1 ; 1}^{2}=2,71\right)$ sehingga keputusan pengujiannya tolak $\mathrm{H}_{0}$ yang menunjukkan bahwa model regresi binomial negatif lebih baik dibandingkan model regresi Poisson dalam menjelaskan pengaruh variabel-variabel prediktor terhadap jumlah pengangguran usia muda.

Berdasarkan persamaan regresi binomial negatif yang diperoleh, variabel UMK $\left(\mathrm{X}_{1}\right)$ memiliki pengaruh positif signifikan terhadap jumlah pengangguran usia muda. Nilai koefisien sebesar 0,2879 menunjukkan bahwa peningkatan UMK sebesar satu juta rupiah akan menambah jumlah pengangguran usia muda sebesar 
$(1,3337-\exp (0)) \times 100=33,37$ persen dengan asumsi variabel lain konstan. Hal ini sejalan dengan penjelasan Borjas (2005) yang menyatakan bahwa peningkatan upah minimum akan meningkatkan biaya produksi, salah satu cara untuk mengurangi biaya produksi tersebut adalah adanya penurunan permintaan tenaga kerja dengan tidak membuka lowongan pekerjaan baru dan berpotensi untuk mengurangi tenaga kerja yang sudah ada. Hasil penelitian ini juga sejalan dengan penelitian yang dilakukan oleh Gorry (2013) dan Ebaidalla (2016) yang menyatakan pengangguran usia muda sangat sensitif dan akan terdampak terhadap kenaikan upah minimum. Anggapan pekerja usia muda kurang memiliki pengalaman dan keterampilan menjadikan mereka rentan untuk diberhentikan dari pekerjaan ketika upah minimum dinilai naik terlalu tinggi.

Variabel persentase serapan tenaga kerja pada sektor pertanian dan sektor industri pengolahan $\left(\mathrm{X}_{23}\right)$ memiliki pengaruh negatif signifikan terhadap jumlah pengangguran usia muda. Nilai koefisien sebesar 0,0120 menunjukkan peningkatan satu persen serapan tenaga kerja pada sektor pertanian dan sektor industri pengolahan akan mengurangi jumlah pengangguran usia muda sebesar $(\exp (0)-0,9881) \times 100=1,19$ persen dengan asumsi variabel lain konstan. Elhorst (2003) menjelaskan bahwa secara umum angka pengganda tenaga kerja (employment multiplier) pada sektor pertanian dan sektor industri pengolahan lebih besar dibandingkan sektor lainnya (sektor jasa) yang menunjukkan kedua sektor ini akan menyerap lebih banyak tenaga kerja dalam upaya mendorong peningkatan produksi. Kaitannya dengan pengangguran usia muda, sektor pertanian dinilai mudah untuk dimasuki tenaga kerja usia muda karena biasanya tidak menuntut tingkat pendidikan dan keterampilan yang tinggi jika dilihat dari jenis pekerjaannya (Nugroho, Waluyati, \& Jamhari, 2018). Hasil penelitian ini sejalan dengan penelitian Muhtamil (2017) dan Daud (2017) yang menyatakan bahwa pertumbuhan sektor industri pengolahan dan sektor pertanian secara langsung akan berdampak positif terhadap penyerapan tenaga kerja sehingga mampu mengurangi pengangguran.

Variabel pertumbuhan ekonomi $\left(\mathrm{X}_{4}\right)$ memiliki pengaruh negatif signifikan terhadap jumlah pengangguran usia muda. Nilai koefisien sebesar -0,0774 menunjukkan peningkatan satu persen pertumbuhan ekonomi akan mengurangi jumlah pengangguran usia muda sebesar $(\exp (0)-0,9255) \times 100=7,45$ persen dengan asumsi variabel lain konstan. Hal ini sejalan dengan penjelasan Mankiw (2010) yang menyatakan bahwa pertumbuhan ekonomi akan mendorong peningkatan produksi barang dan jasa. Peningkatan produksi tersebut akan mendorong penggunaan faktor produksi yang salah satunya adalah tenaga kerja sehingga adanya pertumbuhan ekonomi akan menyerap tenaga kerja dan mengurangi pengangguran. Hasil penelitian ini juga sejalan dengan penelitian Choudhry, Marelli, dan Signorelli (2012) yang mengungkapkan bahwa perubahan kondisi perekonomian memiliki dampak yang besar terhadap pengangguran usia muda, bahkan dampaknya lebih besar dibandingkan terhadap pengangguran secara umum.

Variabel APK SMA $\left(\mathrm{X}_{5}\right)$ memiliki pengaruh negatif signifikan terhadap jumlah pengangguran usia muda. Nilai koefisien sebesar -0,0080 menunjukkan peningkatan satu satuan APK SMA akan mengurangi jumlah pengangguran usia muda sebesar $(\exp (0)-0,9920) \times 100=0,80$ persen dengan asumsi variabel lain konstan. Hal ini sejalan dengan penjelasan Salvador dan Killinger (2008) dan Dietrich (2012) yang menyatakan salah satu cara mencegah dan mengurangi pengangguran usia muda adalah meningkatkan partisipasi kelompok usia muda tersebut dalam pendidikan, semakin besar proporsi kelompok usia muda yang berpartisipasi dalam pendidikan maka pengangguran usia muda cenderung menurun.

\section{KESIMPULAN}

Berdasarkan hasil dan pembahasan, beberapa kesimpulan yang dapat ditarik dari penelitian ini adalah jumlah pengangguran usia muda di Provinsi Jawa Timur pada tahun 2019 ada sebanyak 478.478 orang atau setara 57,29 persen dari total pengangguran keseluruhan. Berdasarkan peta sebarannya, terdapat lima kabupaten/kota dengan jumlah pengangguran usia muda kategori tinggi, yaitu Kabupaten Sidoarjo, Kabupaten Jember, Kabupaten Pasuruan, Kabupaten Malang, dan Kota Surabaya. Jumlah pengangguran usia muda terendah terdapat di Kota Mojokerto hanya sebanyak 667 orang, sedangkan jumlah pengangguran usia muda tertinggi terdapat di Kota Surabaya sebanyak 45.953 orang.

Berdasarkan hasil analisis, diperoleh bahwa variabel upah minimum kabupaten/kota berpengaruh positif signifikan terhadap jumlah pengangguran usia muda, sedangkan variabel persentase serapan tenaga kerja pada sektor pertanian dan sektor industri pengolahan, pertumbuhan ekonomi, dan APK SMA berpengaruh negatif signifikan terhadap jumlah pengangguran usia muda. Adapun variabel persentase angkatan kerja usia muda lulusan SMA/sederajat dan investasi berpengaruh tidak signifikan terhadap jumlah pengangguran usia muda.

Berdasarkan kesimpulan yang diperoleh, beberapa saran yang dapat diajukan diantaranya pemerintah daerah diharapkan lebih mampu melakukan pemerataan akses dan kesempatan pendidikan minimal sampai jenjang SMA/sederajat bagi kelompok usia muda di seluruh wilayah, khususnya wilayah yang masih memiliki APK SMA rendah, seperti Kabupaten Bangkalan, Kabupaten Probolinggo, dan kabupaten/kota lainnya. 
Pemerintah daerah juga diharapkan lebih mampu meningkatkan sektor pertanian dan sektor industri pengolahan (tanpa meninggalkan sektor lainnya) yang disesuaikan dengan potensi dan karakteristik wilayah kabupaten/kota masing-masing.

Penelitian ini belum mempertimbangkan adanya pengaruh kewilayahan (spasial) dan perkembangan variabel dari waktu ke waktu. Oleh karena itu, penelitian pengangguran usia muda selanjutnya dapat menggunakan metode analisis alternatif, seperti analisis regresi spasial dan analisis regresi data panel.

\section{DAFTAR PUSTAKA}

Bappenas. (2003). Kebijakan upah minimum dan perluasan kesempatan kerja. Jakarta: Bappenas.

Bell, D.N.F., \& Blanchflower, D.G. (2011). Young people and the great recession. Oxford Review of Economic Policy, 27 (2), 241-267.

Borjas, G.J. (2005). Labor economics ( $\left.3^{r d} e d\right)$. New York: McGraw-Hill Irwin.

BPS. (2020). Keadaan angkatan kerja di Indonesia Agustus 2020. Jakarta: BPS.

Choudhry, M.T., Marelli, E., \& Signorelli, M. (2012). Youth unemployment rate and impact of financial crises. International Journal of Manpower, 33 (1), 76-95.

Daud, N. (2017). The effect of sector economic growth on the performance of employment and welfare of people. International Journal of Business and Management, 12 (9), 194-203.

Dewi, M.P. (2019). Hubungan Kausalitas Investasi dan Pengangguran di Indonesia [Skripsi]. Jember: Universitas Jember.

Dietrich, H. (2012). Youth unemployment in Europe theoretical considerations and empirical findings. Friedrich-Ebert-Stiftung International Policy Analysis.

Dongxu, W., \& Zhongmin, W. (2011). Crime, inequality and unemployment in England and Wales. Applied Economics, 1-28.

Ebaidalla, E.M. (2016). Analysis of youth unemployment in Sub-Saharan Africa: Determinants and possible ways forward. African Journal Economic and Sustainable Development, 5 (4), 302-317.

Elder, S. (2014). Labour market transitions of young women and men in Asia and the Pacific. Geneva: International Labor Office.

Elhorst, J.P. (2003). The mystery of regional unemployment differentials: Theoretical and empirical explanations. Journal of Economics Surveys, 17 (5), 709-748.

Fila, D.T., Mansingh, J.P., \& Legesse, W. (2016). Determinants of youth unemployment: The case of Ambo Town, Oromia, Ethiopia. International Journal of Economics and Business Management, 2 (2), 162-169.

Gontkovičová, B., Mihalčová, B., \& Pružinský, M. (2015). Youth unemployment - current trend in the labour market?. Procedia Economics and Finance, 23, 1680-1685.

Gorry, A. (2013). Minimum wages and youth unemployment. European Economic Review, 57-75.

Hilbe, J.M. (2011). Negative binomial regression $\left(2^{\text {nd }} e d\right.$ ). New York: Cambridge University Press.

ILO. (2001). Youth unemployment and employment policy: A global perspective. Geneva: ILO.

ILO. (2004). Youth employment report in Indonesia: An update. Jakarta: Kantor ILO.

Kabaklarli, E., Hazeler, P., \& Bulus, A. (2011). Economic determinants of Turkish youth unemployment problem: Cointegration analysis. An Article in $4^{\text {th }}$ International Conference On Applied Economics, 25 Agustus - 27 Agustus 2011. Perugia.

Mankiw, N.G. (2010). Macroeconomics ( $7^{\text {th }}$ ed). New York: Worth Publishers.

Maqbool, M.S., Sattar, T.M.A., \& Bhalli, M.N. (2013). Determinants of unemployment empirical evidences from Pakistan. Pakistan Economic and Social Review, 51 (2), 191-207.

Muhtamil. (2017). Pengaruh perkembangan industri terhadap penyerapan tenaga kerja di Provinsi Jambi. Jurnal Perspektif Pembiayaan dan Pembangunan Daerah, 4 (3), 199-206.

Nugroho, A.D., Waluyati, L.R., \& Jamhari. (2018). Efforts of engage youth generation to working on agricultural sector in Yogyakarta Province. Journal of Governance and Political Social UMA, 6 (1), 7695.

Pindyck, R.S., \& Rubinfeld, A.L. (2013). Microeconomics ( $8^{\text {th }} e d$ ). New Jersey: Pearson Education.

Salvador, R.G., \& Killinger, N.L. (2008). An analysis of youth unemployment in the Euro area. European Central Bank Occassional Paper Series No 89.

Saunders, P. (2002). The direct and indirect effects of unemployment on poverty and inequality. The Social Policy Research Centre Discussion Paper No. 118.

Zeb, N., Fu, Q., \& Sharif, M.S. (2014). Foreign direct investment and unemployment reduction in Pakistan. International Journal of Economics and Research, 5 (2), 10-17. 